\title{
Karl Gebhardt (1897-1948): A lost man
}

\author{
JR Silver \\ Retired Consultant in Spinal Injuries and Fellow of the Institute of Sports Medicine
}

\begin{abstract}
Karl Gebhardt (1897-1948) had a distinguished career as professor of sports medicine before the Second World War. He developed sports for the disabled at a specialised orthopaedic clinic at Hohenlychen and was President of the Red Cross in Germany. During the war, Gebhardt also acted as Heinrich Himmler's personal physician and was responsible for medical experimentation on prisoners in the concentration camps at Auschwitz and Ravensbrück. In his capacity as SS consultant surgeon, he treated Reinhard Heydrich (a high ranking Nazi official, also known as 'the Hangman') after an attempt was made on his life. When Heydrich died, Gebhardt was accused of failing to treat him with sulphonamides. To prove his innocence he carried out a series of experiments on Ravensbrück concentration camp prisoners, breaking their legs and infecting them with various organisms in order to prove the worthlessness of the drugs in treating gas gangrene. He also attempted to transplant the limbs from camp victims to German soldiers wounded on the Russian front. He was tried after the war and executed for these crimes in 1948. This paper explores the paradox of a gifted doctor who was also the perpetrator of inhuman crimes.
\end{abstract}

KEYWORDS Gebhardt, Hohenlychen, sports medicine, Ravensbrück, concentration camp, war crimes, moral paradox

DECLARATION OF INTERESTS No conflict of interests declared.

\author{
Correspondence to JR Silver \\ 8 High Street, Wendover, \\ Buckinghamshire, \\ HP22 6EA, UK
}

tel. $+44(0) 1296623013$

e-mail jrussellsilver@btconnect.com
Karl Gebhardt, medical superintendent of the Schutzstaffel (SS) and consultant surgeon of the Waffen SS was executed as a war criminal on 2 June 1948 for his experiments on prisoners at the Ravensbrück women's concentration camp. It is easy to demonise these experiments as being a deviation by a low grade doctor but it must be recognised that, prior to joining the SS, Gebhardt was a distinguished professor of orthopaedics who made an outstanding contribution to the foundation of sports medicine and developed competitive sport for the disabled as a means of therapy. This contradiction is so extraordinary that it is worthy of the effort to understand how such a paradox came about.

\section{KARL GEBHARDT'S MEDICAL CAREER}

Gebhardt was born in 1897 in Haag, Oberbayern (Bavaria). He was a school friend of Heinrich Himmler in Landshut and he was in the same class as Himmler's brother, remaining friends with the family throughout his life. He served in the First World War but was captured and held as a prisoner of war in Scotland. In 1919 he studied medicine at Munich University and qualified with a PhD in 1923. While at Munich University he became an assistant to the world renowned surgeon Ferdinand Sauerbruch (possibly due to the influence of his father who was a high ranking civil servant responsible for medical affairs for the state of Bavaria). Sauerbruch was the inventor of the Sauerbruch arm, an artificial replacement for an amputated upper limb. This no doubt stimulated Gebhardt's interest in rehabilitation. While working with Sauerbruch, Gebhardt developed his interest in hand surgery and achieved his habilitation (a degree or academic qualification more advanced than a PhD) in this field. When Sauerbruch moved to Berlin, Gebhardt remained in Munich and became Eric Lexer's assistant. Lexer was known for his work in plastic and cosmetic surgery. Gebhardt developed his interest in rehabilitation and founded a department for sports medicine there. ${ }^{2}$

Having achieved his habilitation in the reconstructive surgery of the hand at an early age, Gebhardt strove to facilitate the patient's recovery after surgical intervention using two different methods: early physiotherapy and early mobilisation, instituting exercise immediately following surgery. He focused his work on returning the disabled to an active working life, furthering this process by setting up rehabilitation camps at Hohenaschau in Bavaria especially for young people, where they exercised in the fresh air and sunlight for a week at a time. Gebhardt then followed his teacher Sauerbruch to Berlin where he continued his rehabilitation work.

He became the first professor of sports medicine in Berlin and in 1933 was appointed to the Deutsche Hochschule für Leibesübungen (the Academy for Exercise and Physical Education). Sauerbruch headed the Academy from 1932, following the retirement of August Bier. Bier, the father of spinal anaesthesia and intravenous regional 
anaesthesia had also established the science of sports medicine. Gebhardt expanded on Bier's methods, adopting an academic approach to sports medicine and awarding degrees. In 1933 Gebhardt was appointed director of Hohenlychen Hospital which became the first sports medicine clinic in Germany and was generously funded by the government. He was able to develop his ideas and the clinic became renowned, with an operating theatre, a swimming pool and a large team of doctors. Hitler and Hess visited and many celebrities including Jesse Owens, the sprinter, were treated there. ${ }^{2}$

The British Legion visited the clinic in 1936 in an effort to establish friendships with German veterans of the First World War. Their report noted that:

The aim of Dr Gebhardt's training is to make the amputated case so fit and strong and so active with his one leg and one arm that he gets to feel as active and as efficient as the man with two legs or two arms. To this end it is generally six months before the man receives his artificial limb. This also gives time for the stump to get hardened and to assume its final form.A temporary artificial limb is supplied in the meantime but the constant use of this is not encouraged. ${ }^{3}$

The Legion representatives saw:

...men hopping about on one leg, playing football with men with one arm, the armless men having to use their one arm and not their feet. Two onelegged men were boxing vigorously. We saw onelegged men doing the high jump, one man jumping nearly 4 feet in height. Heavy weights had to be lifted and tossed about. All the men we saw were as brown as a berry and bursting with rude health and muscular activity. ${ }^{3}$

The Legion delegates were impressed by these methods. 'A first rate place cram full of new ideas'. They tried to implement them in this country but British medical opinion advised against it. ${ }^{3}$

The clinic subsequently became a hospital for the SS and, during the war, a military hospital for the wounded, under Gebhardt's direction.

Gebhardt contributed much to the development of sports medicine. He wrote articles on rehabilitation, a textbook on sports rehabilitation ${ }^{4}$ and he disseminated his ideas in Germany and throughout the rest of Europe.

In the years leading up to the war, he became the physician in charge of the Olympic Games. Hohenlychen became the sports sanatorium for the Reich and served as the central hospital for the sportsmen and women who participated in the Olympic Games of 1936. Gebhardt became personal physician to Himmler in
1938 and accompanied him on journeys such as the annexation of Bohemia and Austria. Chief surgeon to the SS in 1939-40, he rehabilitated battlefield-injured soldiers at Hohenlychen hospital. In 1943 he was lead physician to the SS and instigated a war invalid sports badge (given to disabled ex-servicemen). Gebhardt became executive president of the German Red Cross in 1945. ${ }^{2}$

\section{GEBHARDT AND THE NAZI IDEOLOGY}

Gebhardt showed early support for the Nazi ideology. He was a member of the Freikorps Epp and the Freikorps Oberland. Freikorps were illegal military units set up before the advent of the Nazi party and mobilised at the end of the First World War to fight communism. He marched with the Munich unit in 1923 in the failed Hitler putsch. In his early work in health camps, the emphasis on physical fitness, notably marching and outdoor exercise, was sympathetic to the Nazi ideology of strengthening the body by exercises and outdoor activities in close association with the soil. The Nazi ideology provided the right climate for sports medicine to develop and Gebhardt had the opportunity to make his career and achieve preeminence. The Nazis were opposed to specialisation but in favour of natural means of treatment such as exercise in the open air, glorification of the human body and they were anti-intellectual. ${ }^{5}$ Sport became important to the Nazi regime as part of the programme of pre-military education as well as propaganda. The national socialist health system was based on prevention and proclaimed that every German was responsible for his health and it was his duty to remain healthy to provide a healthy Volkskörper (body of people). Sport was considered to actively prevent disease and was therefore popular with the Nazi regime. ${ }^{6}$

Gebhardt adopted the Nazi philosophy of rehabilitating people to contribute to society through work; the state was predominant, not the individual. He again identified with the Nazi ideology in his articles on rehabilitation. While he strived to restore the disabled to a useful working life, he espoused Nazi ideas regarding what should be done with those who could not be rehabilitated - the 'inferior'. He agreed that it was necessary to eliminate these people and although he did not write exactly what this would mean, he used the common term Ausschalten des Minderwertigen (elimination of the inferior). ${ }^{7} \mathrm{He}$ clearly espoused the Nazi doctrine of 'life not fit for life'.

\section{GEBHARDT, THE NAZIS AND CAREER ADVANCEMENT}

Doctors benefited in a number of ways from their association with the Nazi party; they were the highest percentage of members among all the professions. The Nazis attempted to sweep aside the old hierarchical system within the hospitals and create a new regime by 
placing Nazi doctors in important positions. Financially, the doctors benefited when the dismissal of Jewish doctors enabled them to take over their practices, their insurance work and their appointments in the hospitals. Fundamental research was carried out by the Nazis and although it is not credited, their work on cancer research for example was of outstanding scientific value, as later acknowledged by Doll. ${ }^{8}$

Doctors also made use of the facilities made available by the Nazis. Sigmund Ruff did aerodynamic high altitude experiments.' Joseph Mengele and Otmar Verschuer carried out experiments on twins and hereditary diseases. ${ }^{6}$ Julius Hallervorden benefited from studying the brains obtained during the Nazi euthanasia programme. ${ }^{5}$ Gebhardt was not alone in profiting from the Nazi regime. ${ }^{10}$

Gebhardt maintained his friendships with Heinrich Himmler (the head of the SS) and Gerhard Wagner (a powerful figure in the medical community) from the beginning of his career, ensuring both medical and political support. Wagner, a committed Nazi, had also been a member of the Freikorps. As Chief Physician of the Reich (Reichsärzteführer),Wagner gradually gathered power within the medical profession, acting as a plenipotentiary over the doctors. He controlled the administration of the insurance companies and decided who should be licensed and who should be paid. Wagner dominated the medical faculties in schools and universities, through the Fachschaft, a political indoctrination party. Through this organisation, he was able to control the syllabus and therefore the medical students. Wagner's power was absolute within the medical profession and his friendship ensured that all professional doors would be opened to Gebhardt. On the political side, Gebhardt maintained his friendship with Himmler. He thus had both medical and political support to further his career.This influence can be seen several times throughout his career, most notably in Berlin and Bavaria.

The surgical clinic and the sports and exercise academy in Berlin had been under the control of August Bier (186I-1949) until his retirement in 1932. When the Nazis came to power, Bier's deputy, Carl Diem (18821962), and Diem's associates were dismissed because they were Jewish. Both the surgical department and the sports and exercise clinic were closed down in 1933. When they re-opened, Sauerbruch temporarily succeeded to the post before Gebhardt was put in charge. Gebhardt's career directly benefited from the Nazi 'cleansing' policy as the 'cleansing' of the institutes made the post of director available to him.

When Gebhardt went to Hohenlychen in 1933, it was a sanatorium for the treatment of tuberculosis. Again, the physician in charge, Eugen Kisch, was Jewish and it was

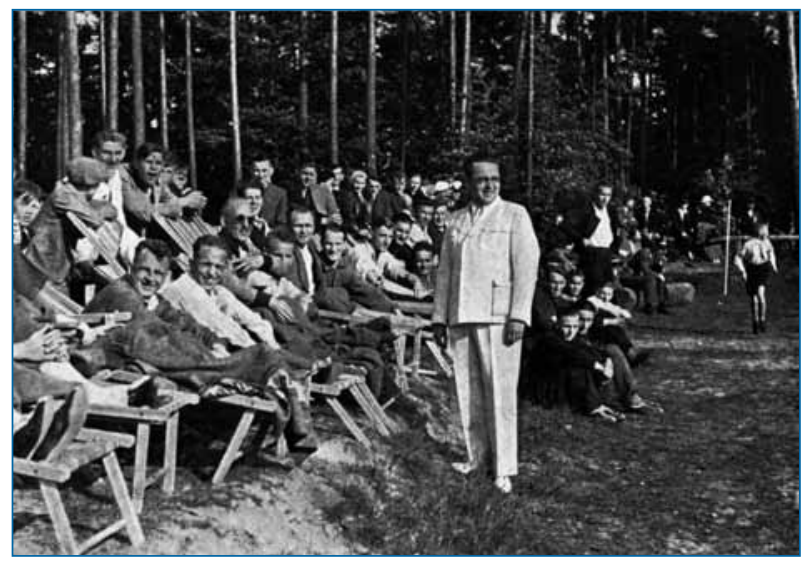

FIGURE I Karl Gebhardt and patients at Hohenlychen circa 1936. Reproduced by kind permission of Historischer Verein für Niederbayern.

closed down in 1933 under the Nazi racial laws. It re-opened under the aegis of the SS and money was poured into it. Gebhardt was put in charge and he instituted Nazi policies, benefiting fully from the facilities and developing his own ideas, particularly rehabilitation by sport and exercise therapy. The objective was for Gebhardt to build up the medical institute within the academy and Hohenlychen provided him with the facilities to do practical research and rehabilitation training in sports medicine (Figure I).

Hitler had initially been opposed to the Olympic Games being held in Berlin in 1936, as he considered them to be Jewish and communist-run but Joseph Goebbels, the propaganda minister, convinced him. The Berlin Olympics became a showplace for Nazi ideas, a propaganda tool extolling the virtues of the Nazi state, with the government funding the building of the sports stadia. In 1936, Gebhardt became the chief physician to the Olympic Games. ${ }^{2}$

\section{THE EXPERIMENTS IN THE CONCENTRATION CAMPS}

There was a precedence for unethical experiments on patients in Germany, evidenced by the work of Albert Neisser who, in 1898, infected prostitutes with syphilis." Prior to the Second World War, experimentation on humans was thought to be a legitimate approach throughout the world (with the Tuskegee Syphilis Study, started in the USA in 1932 proving the most famous example). ${ }^{12}$ With the Second World War, Nazi ideology and a permissive approach to human experimentation combined to justify the medical experiments inflicted on the 'inferior' in Germany. This process was facilitated by the secrecy and the lack of restrictions prevalent in the concentration camps.

During the war, some doctors gave qualified approval to the concentration camps, while many passively acquiesced. Some, like Gebhardt, used the facilities put at 
their disposal to further their careers and in Gebhardt's case, he was able to initiate his medical experiments. He did not just benefit from the opportunities that arose, like Sauerbruch, with qualified acceptance of the regime. He took the initiative and organised teams of doctors at Ravensbrück to further his research. He had a large number of doctors working for him both at Hohenlychen and at Ravensbrück concentration camp and was responsible for the supervision of the doctors and experiments in other camps. He derived prestige from being chief doctor to the Olympic Games and power from being chief doctor to the SS and his involvement with the Red Cross.

He supported, organised and carried out a series of experiments on concentration camp inmates involving transplantation, anaesthesia and the use of sulphonamides in the treatment of sepsis in war wounds. At that time, the use of sulphonamides was controversial.While some doctors, including Gebhardt, believed they were useless, others such as Gebhardt's superior, Ernst-Robert Grawitz, held a different opinion. The matter came to a head with the well-publicised death of Reinhard Heydrich.

\section{The Hangman}

Heydrich was head of the Reich security services and deputy of the Reich protectorate of Czechoslovakia. He travelled in an open-top Mercedes car from his home to the castle where he worked, providing an easy target for the British-trained Czech agents who had been flown into Prague to assassinate him in May 1942. An agent stepped in front of Heydrich's vehicle but his Sten gun jammed. Heydrich stood up to shoot him and another assassin threw an anti-tank grenade into the car. It ripped through the right rear fender of the car, embedding shrapnel and fibres from the seats into Heydrich's body. He was taken to Bulovka Hospital where Professor Hollbaum operated to re-inflate his collapsed left lung, remove the tip of a fractured rib, suture the diaphragm and remove the spleen. Heydrich seemed to recover well the next day but by the time Himmler's personal physician, Gebhardt, arrived to take full charge of the patient, Heydrich had developed a fever. He collapsed in shock seven days later and died. It would appear that post-operative care included the administration of large quantities of morphine but no sulphonamides and the patient was said to have died from septicaemia. Himmler accused Gebhardt of negligence for not treating him with sulphonamides and told Gebhardt that the only way he could prove that Heydrich's death was 'fate determined' and not due to negligence was to carry out large scale experiments to try and prove that infected people died of gas gangrene whether they were treated with sulphonamides or not. This is the statement that Gebhardt gave to Leo Alexander at the Nuremberg trials ${ }^{9}$ (Figure 2). Alexander, an Austrian-born American psychiatrist, acted as an aide at the Nuremburg War Crimes trials, and wrote the Nuremburg Code of Ethics after the War.

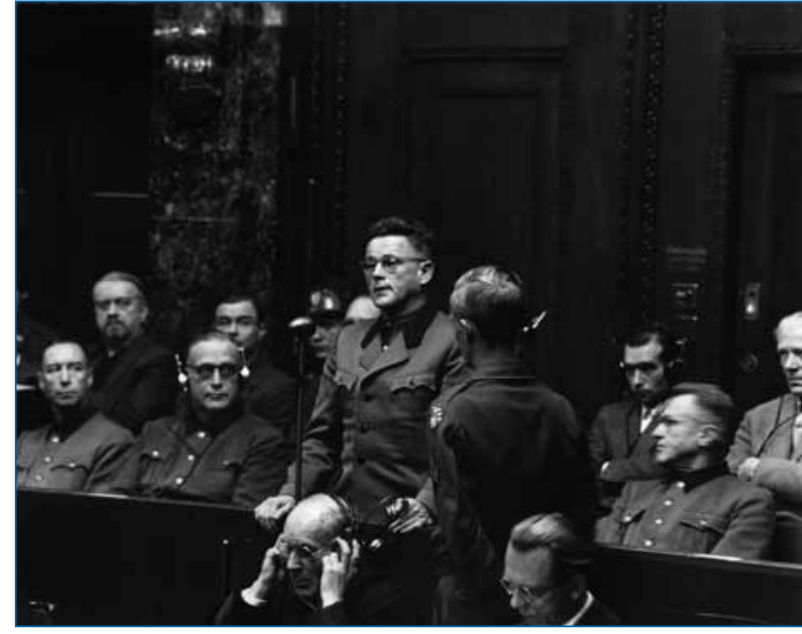

FIGURE 2 Karl Gebhardt pleading 'not guilty' in Nuremburg in 1946. Reproduced by kind permission of Stadtarchiv Nürnberg.

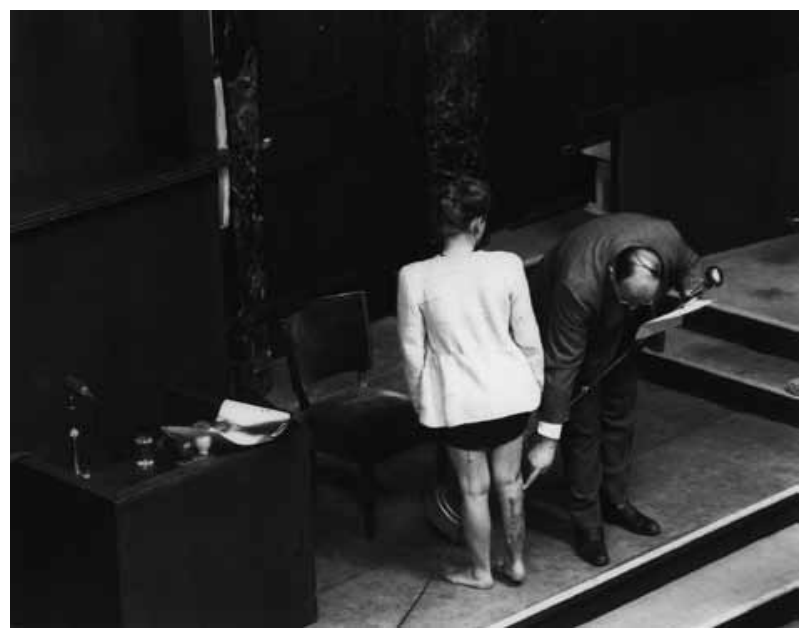

FIGURE 3 A surviving victim of the war experiments done at Ravensbrück, showing her injuries at the Nuremburg trials in 1946. Reproduced by kind permission of Stadtarchiv Nürnberg.

These exculpatory experiments were carried out by Gebhardt, Fritz Fischer and Herta Oberheuser at Ravensbrück concentration camp. Patients had their legs deliberately fractured and the wounds were infected with virulent bacteria. Half the prisoners were given sulphonamides and the remainder were left untreated. ${ }^{13}$ All the prisoners suffered overwhelming infection and excruciating pain. The majority were executed but some survived and it was on the basis of their evidence at the Nuremberg trials that Gebhardt was condemned to death (Figure 3).

Further experiments were carried out at Gebhardt's direct instigation in order to further his research on the rehabilitation of the limbs. In one, he endeavoured to transplant the scapula and shoulder of a prisoner from the concentration camp at Ravensbrück to a soldier at Hohenlychen who had lost a shoulder as a result of a sarcoma. The operation was carried out by Fischer, 
despite his protestations, because Ludwig Stumpfegger, who should have performed this operation, was required by Gebhardt to assist him at Hohenlychen. Interestingly, these experiments were opposed by his SS subordinates at Hohenlychen, who disagreed with both the theoretical basis of the work being carried out and the practical implementation. Another prisoner had his legs amputated and carried away in a sack by Gebhardt who then attempted to attach them to a soldier whose lower limbs had been amputated at Hohenlychen hospital. The experiments were presented to a group of senior physicians (including Sauerbruch) in May 1943, and while the technical aspects were discussed, there was no opposition to the ethical implications. Gebhardt also carried out further experiments to see how the patients could survive painful operations. ${ }^{14}$ Gebhardt was recognised by his peers for his work in sports medicine but despite the criticisms of his subordinates, who opposed him, not on ethical grounds but on technical scientific grounds, he persisted with the transplantation experiments. He argued that he carried out the infection experiments to prove himself innocent in his treatment of Heydrich. Even if one accepts this slender excuse, it does not absolve him. The transplantation experiments were totally at his own initiative.

At his Nuremburg trial, he showed no remorse and defended his actions saying that he took full responsibility and it was the best method of proving his work. Gebhardt was executed in 1948 for his experiments in the concentration camps.

Experiments were carried out in many concentration camps. They were not the isolated work of a single man; Gebhardt was part of a group which included Karl Brandt, Hitler's personal physician and General Commissioner for Health and Sanitation. Himmler and Hitler were also fully aware of the experiments taking place in the camps. The work was coordinated from above, carried out without the consent of the victims and was totally different to the scientific research of the Allies. The Nazi research was thanatology, the science of killing people, as opposed to trying to cure them. Moreover, Gebhardt was deeply immersed in the politics and the machinations of the Nazi party at the highest level. Later in the war, he was accused of being involved in an attempt to medically kill Albert Speer, the only Nazi to admit he was ashamed of what he did. ${ }^{12,15}$

\section{GEBHARDT'S ACHIEVEMENTS}

Gebhardt was an able man. He had achieved his habilitation prior to joining the Nazi party, in contrast to Joachim Mugrowski, Fischer, Mengele and Sigmund Rascher (other SS doctors who carried out experiments in the camps), who did not achieve their habilitation. ${ }^{5}$ Gebhardt was regarded as an expert in his field. He profited from the dismissal of the Jewish doctors at
Hohenlychen and the Berlin Clinic and as a result he inherited a hospital and a department to further his treatment and research. That he made his career within the Nazi party was not just fortuitous.

\section{GEBHARDT'S LEGACY}

It is acknowledged that sports medicine developed in Germany in 1928. When the British Medical Journal wrote on the subject, they quoted Professor Bier as the pioneer in the field. ${ }^{16}$ The specialty was developed by Gebhardt, initially in Munich and Hohenlychen where he showed how sports medicine could be applied for rehabilitation. With the advent of the war, Germany was cut off from the rest of the world. The widespread destruction of war and the impact of the Nazi influence meant that any German discoveries were not recognised or acknowledged. As a result of the horrors perpetrated by the Nazis, scientists did not go to Germany to study. After the war, sports medicine began to develop in Holland at $\mathrm{PhD}$ level and in the United Kingdom there were a variety of private sports clinics. However despite the efforts of a devoted band of doctors, there were no sports facilities within the National Health Service. Even today, the facilities are severely curtailed. ${ }^{17}$

Only when a German-Jewish refugee, Sir Ludwig Guttmann, came to Britain did the message about sports medicine emerge from Germany and lead to the introduction of sports for the disabled. Guttmann is usually credited with starting the paralympic sports movement from which the Paralympic Games arose. $\mathrm{He}$ would most likely have been influenced by Gebhardt's early work in Germany and, however distasteful, his later work. Despite his subsequent atrocities, Gebhardt's contribution to sports medicine and sports for the disabled should be acknowledged.

\section{CONCLUSION - THE PARADOX OF KARL GEBHARDT}

Had Gebhardt not joined the Nazi party, he would not have been in a position to develop sports medicine. The moral dilemma is that Gebhardt achieved a position of power and authority through the Nazi party and as a result, he was able to found and develop the speciality of sports medicine and develop competitive sport for the disabled as a means of therapy, a great benefit to mankind. In his powerful role as a Nazi doctor and director of the Hohenlychen clinic, he was able to carry out cruel, inhuman experiments in the concentration camps and at the clinic. It is a dreadful paradox that some of these experiments were carried out by the same man in the same sports clinic and resulted in his execution. It shows what a fine line scientists can tread. The end can never justify the means. 
It might seem at times inhibiting to carry out research in today's climate of supervision. Yet in an environment with no checks and safeguards, inhumane, unjustifiable experiments could be readily carried out by doctors such as Gebhardt with the support of the state. As a result of the Nuremberg trials, a code was drawn up and experimentation on humans without informed consent was banned..$^{18}$ It was the activities of energetic and capable people that enabled the Nazi party to succeed and Gebhardt was one of them. He was a leader, an organiser and an innovator.

As Napoleon reputedly observed, when a general is both intelligent and energetic, there is a danger that his mistakes become magnified as he applies his energy to drive his mistakes into disasters.

\section{REFERENCES}

I Holocaust Education and Archive Research Team [Internet]. Reinhardt Heydrich. Available at: http://www.holocaustresearchproject.org/ holoprelude/heydrich.html

2 Hahn J. Grawitz, Genzken, Gebhardt: drei karrieren im sanitätsdienst der SS. Münster: Klemm \& Oelschläger; 2008. Personal communication (I3 February 20II).

3 Wootton G. The official history of the British Legion. London: Macdonald and Evans Ltd; 1956. p. 186.

4 Chirurgische Krankengymnastik [Book Review]. BJS 1933; 20:708. http://dx.doi.org//0.1002/bjs. I800208042

5 Kater MH. Doctors under Hitler. Chapel Hill and London: The University of North Carolina Press; 1989. p.25, I31, 36 I.

6 Weyers W, Ackerman A, editors. Death of medicine in Nazi Germany: dermatology and dermatopathology under the swastika. Philadelphia:Ardor Scribendi Ltd; 1998. p. I40, 335.

7 Hahn J. Personal communication (30 November 2010).

8 Proctor RN. The Nazi war on cancer. Princeton, New Jersey: Princeton University Press; 1999. p. 217.

9 Mitscherlich A, Mielke F. Doctors of infamy: the story of Nazi medical crimes. New York: Henry Schuman; 1949. p. xxxii, xxi, 6.

10 Silver JR. The German-speaking world. In: History of the treatment of spinal injuries. New York: Kluwer Academic/Plenum Publishers: 2003. http://dx.doi.org//0.1007/978-I-44/9-899|-8_7

\section{Acknowledgements}

I wish to thank Professor PaulWeindling for his constructive input. I am indebted to Dr Judith Hahn for her meticulous research and her contribution to the paper by repeatedly answering queries and providing evidence and illustrations from her comprehensive book. Finally, I wish to express my gratitude to the British Legion and particularly to Harry Harris, the producer of a programme transmitted on the Discovery Channel, documenting a visit, by British Legion members, to Germany in 1936.

I I Vollmann J,Winau R. Informed consent in human experimentation before the Nuremberg Code. BMJ 1996; 313:1445-47.

12 Schmidt U. Justice at Nuremberg: Leo Alexander and the Nazi doctors trial. Basingstoke: Palgrave Macmillan; 2006. p. I59-259, 284.

13 Ebbinghaus $\mathrm{A}$, Roth $\mathrm{KH}$. Die kriegschirurgischen experimente in den konzentrationslagern und ihre hintergründe. In: Ebbinghaus $A$, Dörner K.Vernichten und heilen. Der Nürnberger Ärzteprozeß und seine folgen. Berlin:Aufbau-Verlag; 200I. p. I77-2I8.

14 Machlejd W, editor. Experimental operations on prisoners of Ravensbrück Concentration Camp. Warsaw: Zachnodnia Agencja Prasowa; 1960.

15 Schmidt U. Karl Brand, the Nazi doctor: medicine and power in the Third Reich. London: Hambledon Continuum; 2008. p.245-39I.

16 [Editorial]. Sports doctors. BMJ 1928; I:365-66. http://dx.doi. org/I0.II36/bmj.I.3504.36I-a

17 McLatchie GR. Essentials of sports medicine. Edinburgh and New York: Churchill Livingstone; 1986.

18 Weindling P. The origins of informed consent: the International Scientific Commission on MedicalWar Crimes, and the Nuremberg Code. Bull Hist Med 200I; 75:37-7I. http://dx.doi.org/I0.1353/ bhm.200I.0049 